UDK: 343.77:28-523.4::[28:061.234(497.6)](497.6-21KLJUČ) Izvorni naučni rad Primljeno: 30. 9. 2019. Prihvaćeno za štampu: 13. 1. 2020.

mr. sci. Ermin Vučkić

Glavni imam Medžlisa IZ Ključ

E-mail:erminvuckic@yahoo.com

dr. sci. Mujo Begić, docent

Univerzitet u Bihaću

Islamski pedagoški fakultet, Pedagoški fakultet

Institut za nestale osobe $\mathrm{BiH}$ - Područni ured Bihać

E-mail:mujo_begic@hotmail.com

\title{
UNIŠTAVANJE DŽAMIJA I DRUGIH OBJEKATA ISLAMSKE ZAJEDNICE BOSNE I HERCEGOVINE NA PODRUČJU OPĆINE KLJUČ
}

\section{Sažetak}

Tokom agresije na Republiku Bosnu i Hercegovinu vjerski objekti i druga imovina Islamske zajednice u Bosni i Hercegovini bila je izložene napadu srpskih vojnih i policijskih snaga bez ograničenja. Uništavanje, devastacija, pljačka $i$ bezobzirno razaranje imalo je za cilj brisanje tragova postojanja islama i Bošnjaka na ovim prostorima. Uništavajući džamije, mesdžide, imamske kuće, mezarja i drugu vakufsku imovinu nanesena je ogromna materijalna šteta Islamskoj zajednici. Uništeni su brojni vjerski objekti koji su bili zaštićeni kulturno-historijski spomenici. Po identičnom scenariju na meti pripadnika srpskih vojnih i policijskih snaga uništene su ili u značajnoj mjeri oštećene ď̃amije i druga imovina Islamske zajednice na području općine Ključ.

Ključne riječi: agresija, džamije, uništavanje i devastacija imovine Islamske zajednice u Bosni i Hercegovini.

\section{Uvod}

Karakteristika agresije na Republiku Bosnu i Hercegovinu, između ostalog, bila je masovno uništavanje stambenih, privrednih, kulturno- 
historijskih i vjerskih objekata. ${ }^{1}$ Srpske snage su u Republici Bosni i Hercegovini (u svim okupiranim mjestima i gradovima u opsadi, posebno u okupiranim mjestima, sigurnim zonama Ujedinjenih nacija, te slobodnim područjima), planski, organizovano, sistematski i s namjerom, uništavale historijska, vjerska i kulturna dobra Bošnjaka i države Republike Bosne i Hercegovine, te namjerno nanosile štetu tim dobrima, s ciljem da izbrišu sve dokaze njihovog postojanja. ${ }^{2}$

Pitanje zaštite kulturnih dobara u oružanim sukobima regulisano je Konvencijom za zaštitu kulturnih dobara u slučaju oružanog sukoba (dalje: Konvencija) iz 1954. godine. U članu 1. Konvencije pod kulturnim dobrima smatra se: a) pokretna i nepokretna dobra koja su od velikog značaja za kulturnu baštinu naroda, kao spomenici: arhitekture, umjetnosti ili historije, vjerski ili laički, arheološka mjesta, skup građevina koje su kao cjelina od historijskog ili arheološkog interesa, umjetnička djela, rukopisi, knjige i drugi predmeti umjetničkog, historijskog ili arheološkog interesa, kao i naučne kolekcije i važne kolekcije knjiga, arhiva ili reprodukcija naprijed navedenih dobara; b) zgrade, čija je glavna i efektivna namjena da čuvaju ili da izlažu pokretna kulturna dobra navedena u alineji: a), kao muzeji, velike biblioteke, arheološka skladišta, kao i skladišta određena za sklapanje pokretnih kulturnih dobara navedenih u alineji a) u slučaju oružanih sukoba; c) centri u kojima se nalazi značajan broj kulturnih dobara, koja su navedena u alinejama a) i b), takozvani centri u kojima su sakupljeni kulturni spomenici. ${ }^{3}$ Kada je u pitanju agresija na Republiku Bosnu i Hercegovinu, sa sigurnošću možemo reći da je u Republici Bosni i Hercegovini porušeno najviše vjerskih objekata. Prema podacima Islamske zajednice, u Bosni i Hercegovini uništeno je 614 džamija, 218 mesdžida, 69 mekteba, 4 tekije, 37 turbeta, te 405 vakufskih objekata.

\footnotetext{
${ }^{1}$ Mujo Begić, Bosanska Krupa 1992-1995. - Porušeni grad (dalje BOSANSKA KRUPA ...), Institut za istraživanje zločina protiv čovječnosti i međunarodnog prava Univerziteta u Sarajevu, Sarajevo, 2016, str. 238.

${ }^{2}$ Smail Čekić, Dejtonski (mirovni) sporazum - Legalizacija genocida u Republici Bosni i Hercegovin (dalje DEJTONSKI ...), Institut za istraživanje zločina protiv čovječnosti i međunarodnog prava Univerziteta u Sarajevu, Sarajevo, 2016, str. 904.

${ }^{3}$ Zbirka propisa, Međunarodne konvencije o ratnom pravu i sigurnosti, ZONO, Zagreb, 1979, str. 252.
} 
Oštećeno je 307 džamija, 41 mesdžid, 18 mekteba, 5 tekija, 7 turbeta, te 149 vakufskih objekata. ${ }^{4}$

Mnogi od oštećenih ili srušenih objekata bili su kulturno-historijski spomenici, pa je teško i procijeniti kolika je šteta učinjena njihovim uništavanjem. Neprocjenjiva šteta nanesena je uništavanjem ili oštećenjem Gazi Husrev-begove džamije, Ali-pašine džamije, džamije Magribije, Aladže i Careve džamije u Foči, džamije Fethije, Karađozbegove džamija, Ferhadije i Arnaudije u Banjoj Luci, Emin Turhanbegove džamije u Ustikolini. ${ }^{5}$

Postavlja se pitanje zašto su uništavani vjerski objekti muslimana na području općine Ključ. Odgovor je jasan - trebalo je uništavajući vjerske objekte i druge spomenike koji se identificiraju s Bošnjacima uništiti svjedočanstvo o postojanju primarno Bošnjaka - muslimana na ovim prostorima. Ovi vjerski objekti su uništavani na različite načine: podmetanjem eksploziva, podmetanjem požara, direktnim gađanjem artiljerijskim ili protivoklopnim i protivavionskim oružjem ili oruđem. Najveći broj je najprije zapaljen, porušen i oštećen podmetanjem eksploziva a onda dodatno ili potpuno razaran građevinskim mašinama. ${ }^{6}$ Pored džamija uništeni su mesdžidi, imamske kuće, tekije, turbeta, mezarja i druga imovina Islamske zajednice u Bosni i Hercegovini.

Počinioci i naredbodavci rušenja vjerskih objekata često su se izjašnjavali kao vjernici. Rušeći vjerske objekte, pokazali su se i kao bogohulnici i barbari, a ne vjernici. Značajnu ulogu u stvaranju mržnje prema islamu i muslimanima odigrali su srpski intelektualci koji su nastojali da stvore krive predodžbe o muslimanima kao stranom, tuđem, inferiornom i prijetećem faktoru. U pripremnoj fazi se odigralo stvaranje antiislamske atmosfere koja je omogućila potonje skliznuće u

\footnotetext{
${ }^{4}$ Muharem Omerdić, Prilozi izučavanju genocida nad Bošnjacima (1992-1995) (dalje PRILOZI ...), El-Kalem, Sarajevo, 1999, str. 476.

${ }^{5}$ M. Omerdić, PRILOZI ...., str. 15.

${ }^{6}$ M. Begić, BOSANSKA KRUPA ..., str. 239.

${ }^{7}$ Isto, str. 239.
} 
genocid nakon što je izbio otvoreni sukob aprila 1992. godine u Bosni i Hercegovini. ${ }^{8}$

Kakav je bio odnos pojedinih pripadnika VRS prema islamu govori izjava pukovnika Pere Čolića, komandanta 5. kozarske brigade VRS, na proslavi godišnjice brigade, kada je, između ostaloga, izjavio: "I svi mi skupa, u Srbiji i Crnoj Gori, kao što su naša braća iz ovih srpskih zemalja, od početka sa nama i u borbi protiv ustaša i islama."9

Prema podacima iz vjerskih zajednica, samo na području banjalučkog i bihaćkog muftijstva srušeno je 205 džamija. ${ }^{10}$

Među onima koji su prvi ubijani bili su vjerski službenici. ${ }^{11} \mathrm{U}$ nekim džamijama agresor je ubijao i spaljivao civile. ${ }^{12}$ U naselju Hanifići (Kotor-Varoš) u džamiji je pobijeno više civila i spaljeno. Isti dan (14. augusta 1992. godine, prim. M. B.) pobijeno je više muslimana u džamiji u Hanifićima. Zamotali su ih u ćilime i palili uz pomoć benzina. $^{13}$ Identičan slučaj je sa imamom Sulejmanom ef. Dizdarevićem i njegovim džamatlijama koji su ubijeni ispred džamije u Čarakovu (Prijedor) nakon čega su zapaljeni. ${ }^{14}$ Posebno bismo

\footnotetext{
${ }^{8}$ Norman Cigar, Uloga srpskih orijentalista u opravdanju genocida nad Muslimanima Balkana, Institut za istraživanje zločina protiv čovječnosti i međunarodnog prava u Sarajevu, Sarajevo, 2000, str. 23.

9 https://www.youtube.com/watch?v=DmRUM8Av6wU, pristupljeno 3. januara 2016; navedeno u: M. Begić, BOSANSKA KRUPA ..., str. 239.

${ }^{10}$ M. Omerdić, PRILOZI, str. 461-468.

$11 \mathrm{U}$ periodu agresije na Bosnu i Hercegovinu ukupno su ubijene 102 osobe iz Islamske zajednice Bosne i Hercegovine i to: 6 glavnih imama, 61 imam, jedna mualima, 4 profesora, 1 studentica FIN (Fakultet islamskih nauka), 15 učenika Gazi Husrev-begove medrese, jedan mujezin, 3 svršenika Gazi Husrev-begove medrese, 5 penzionisanih imama, 5 službenika zaposlenih pri IZ Bosne i Hercegovine. Vidi više u: Muharem Omerdić, Imami šehidi, Udruženje Ilmije, Sarajevo, 2005.

${ }^{12}$ S. Čekić, DEJTONSKI ..., str. 909.

${ }^{13}$ M. Omerdić, PRILOZI, str. 346.

${ }^{14}$ Mujo Begić, Genocid u Prijedoru, Hrvatski memorijalno-dokumentacijski centar Domovinskog rata Zagreb, Institut za istraživanje zločina protiv čovječnosti i međunarodnog prava Univerziteta u Sarajevu, Zagreb, Sarajevo, 2015, str. 86, Mujo Begić, Senadin Ramić, Zlatan Ališić, Tomašica-masovna grobnica, Institut za istraživanje zločina protiv čovječnosti i međunarodnog prava Univerziteta u Sarajevu, Sarajevo, 2015, str. 33.
} 
izdvojili sudbinu Hasiba ef. Ramića koji je zaklan od strane pripadnika srpske vojske u porodičnoj kući u Semizovcu, zajedno sa suprugom Šefikom i četvero djece (Muhamed, Ahmed, Meliha i Amina). Najmlađa Amina, beba od tri mjeseca je zadavljena. Zločinci su prvo zaklali i udavili djecu, a onda Hasib-efendiju i njegovu suprugu.

Imami s područja općine Ključ bili su među prvima koji su nezakonito zatvarani, mučeni i ubijani. Tu su ubijeni imami Ale ef. Behar i Fikret ef. Balagić.

Fikret ef. Balagić je zarobljen sa svojim džematlijama i komšijama u Biljanima, a ubijen 10. jula 1992. godine. Posmrtni ostaci su pronađeni u masovnoj grobnici Lanište. ${ }^{15}$

Ale ef. Behar uhapšen je mjestu Kamičak od strane srpske policije da bi nakon toga bio odveden u Donju Tramošnju gdje je zatvoren u zgradu osnovne škole. Nakon višednevnog fizičkog mučenje od strane srpskih vojnika ubijen je i zakopan na jednoj livadi na lokalitetu TominaBubulji. Posmrtni ostaci Ale ef. Behara ekshumirani su i identifikovani 10. oktobra 2016. godine. Dženaza i ukop obavljeni su na mezarju u Gornjem Kamičku 15. oktobra 2016. godine. ${ }^{16}$

Jedan broj imama $s$ područja općine Ključ je zatvaran u više koncentracionih logora gdje su bili podvrgnuti teškim psiho-fizičkim torturama. Među nezakonito zatočenim imamima bili su Atif ef. Vučkić, Rešad ef. Jugo i Muharem ef. Posavljak. Nezakonito zatočeni imami bili su izloženi teškim fizičkim i psihičkim maltretiranjima. Tjerani su da jedu svinjsko meso uz razne druge neugodnosti. Od posljedica teških psiho-fizičkih maltretiranja na njihovo zdravlje ostale su trajne posljedice. Imami s područja općine Ključ bili nezakonito zatočeni u koncentracionim logorima: Betonirka, O.Š „Nikola Mačkić“, O.ŠS. „Dobrila Pupićc“ - Sitnica i u koncentracionom logoru Manjača. U logorima su čuvari tjerali imame da jedu svinjsko meso kako bi ih dodatno ponižavali. Tako je u koncentracionom logoru Manjača: logorski čuvar sa nadimkom Bula “ rekao: 'Merhaba hodža!' Hodža nije

15 Mujo Begić Genocid u Ključu (dalje GENOCID U KLJUČU...), Institut za istraživanje zločina protiv čovječnosti i međunarodnog prava, Sarajevo, 2012, str. 218.

${ }^{16}$ Arhiv Instituta za nestale osobe Bosne i Hercegovine - Područni ured Bihać (dalje AINOBiHPUB), Baza podataka. 
odgovarao pa je Bula ponovo rekao: 'Čuješ li ti hodža, šta ja govorim'! - mašući palicom ispred njega. Hodža je rekao da čuje. Pitao je hodžu je li počeo jesti slaninu, hodža je ćutao, a on je opet odgovorio da nije još počeo jesti slaninu a u tanjiru mu je bio komad slanine. Maltretirao ga je tu dosta."17 Imama Muharema Posavljaka postavljali su na dvije stolice, prsima okrenutim prema zemlji, a onda po njemu skakali i pokušavali mu slomiti kičmu. ${ }^{18}$

\section{Uništavanje džamija i druge imovine Medžlisa IZ Ključ}

Osmanska vojska zauzela je srednjevjekovni grad Ključ 1463. godine. Za ovu godinu se vezuje i formiranje džemata, džamije i mekteba. Prema popisu stanovništva iz 1895. godine, na prostoru općine Ključ bilo je 7.326 muslimana ili $33,41 \%$, da bi po popisu iz 1991. godine bilo 17.696 ili 47,33 \% od ukupnog broja stanovništva općine. ${ }^{19}$ Prema podacima iz popisa stanovništva i vjerskih objekata iz 1895. godine, na području Ključa bilo je 17 džamija i 34 mekteba. Prema administrativno-vjerskoj podjeli Rijaseta IZ BiH Medžlis IZ Ključ pripada Banjalučkom muftijstvu.

U kontekstu uništavanja džamija na području općine Ključ u tekstualnom dijelu, u kratkim crtama iznijet ćemo za svaki džemat i nekoliko podataka uz fotografije srušenih džamija. U agresiji na Republiku Bosnu i Hercegovinu, na području Ključa uništeno je 17 džamija. Prema podacima Medžlisa IZ Ključ procijenjena šteta na uništenim džamijama, mektebima i imamskim kućama iznosi 8.965.000 KM (osam miliona devet stotina šezdeset i pet hiljada konvertibilnih maraka). ${ }^{20}$ Džamije na području općine Ključ su potpuno uništene ili

\footnotetext{
${ }^{17}$ AIIZ, inv. br. 2365 , Bosna i Hercegovina, Agencija za istraživanje i dokumentaciju, Sektor AID Sanski Most, broj: 02-1302, 11. august 1997, IZJAVA A.M.

${ }^{18}$ M. Begić, GENOCID U KLJUČU ..., str. 329.

${ }^{19}$ Nacionalni sastav stanovništva, Rezultati za Republiku po opštinama i naseljenim mjestima 1991, Statistički bilten br. 234, Državni zavod za statistiku RBiH, Sarajevo, 1993.

${ }^{20}$ Arhiv Medžlisa IZ Ključ, INFORMACIJA O KULTUROCIDU SAKRALNIH OBJEKATA KULTURNO-HISTORIJSKOG NASLIJEĐA BOŠNJAKA OPĆINE KLJUČ, mart, 1998. godine.
} 


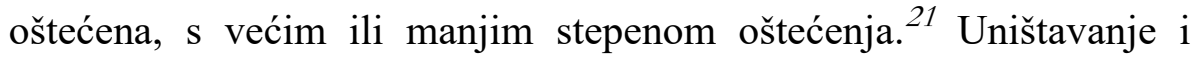
devastacija ovih vjerskih objekata izvršeni su od strane pripadnika srpskih vojnih ili policijskih jedinica. Uništavanje je vršeno paljenjem, miniranjem, djelovanjem artiljerijskih projektila ili na druge načine.

Krizni štab opštine Ključ je svojim propagandnim djelovanjima nastojao umanjiti i relativizirati zločine koje su počinile srpske vojne i policijske snage nad Bošnjacima. U saopštenjima za javnost nastojali su lažima prikriti prave razmjere zločina. U saopštenju broj 6/92 od 2 . juna 1992. godine, navode da su muslimanski ekstremisti rušili vjerske i druge objekte. ${ }^{22}$ Zapravo ovim su htjeli odgovornost za uništavanje vjerskih i objekata za stanovanje prebaciti na Bošnjake.

Prva džamija u Ključu izgrađena je odmah po osvajanju Ključa od strane osmanske vojske 1463. godine. Izgrađena je unutar zidina tvrđave i bio je to, ustvari, vojni mesdžid. Prva džamija je izgrađena 1465. godine. Zapravo, unutar jedne tabor-kule izgrađen je mihrab, tako da je cijeli sprat te kule služio kao džamija. Prema dostupnim podacima prvi mekteb u Ključu sagrađen je 1465, a drugi oko 1550. godine. Druga džamija za koju postoje pisani tragovi izgrađena je 1557. godine. To je bila kamena džamija s drvenim minaretom. Ova džamija se zvala Atik-stara džamija i tri puta je paljena. Atik-džamija (stara džamija) je zapaljena u Drugom svjetskom ratu od strane četničkih jedinica. Gradska džamija sagrađena je 1875. godine. Bila je izgrađena od kamena s drvenim minaretom, dimenzija 15x10 metara. Zapaljena je i uništena tokom Drugog svjetskog rata. Nova (gradska) džamija u Ključu građena je 1980-1989. godine. Dimenzije su bile 17x15 metara, a visina minareta bila je 33 metra. Tokom agresije na Republiku Bosnu i Hercegovinu ova džamija je uništena kao i imamski stan i dva turbeta.

${ }^{21}$ M. Omerdić, PRILOZI ..., str. 38.
${ }^{22}$ AINOBiHPUB, SAOPŠTENJE BR.6/92, 2. juni 1992. 


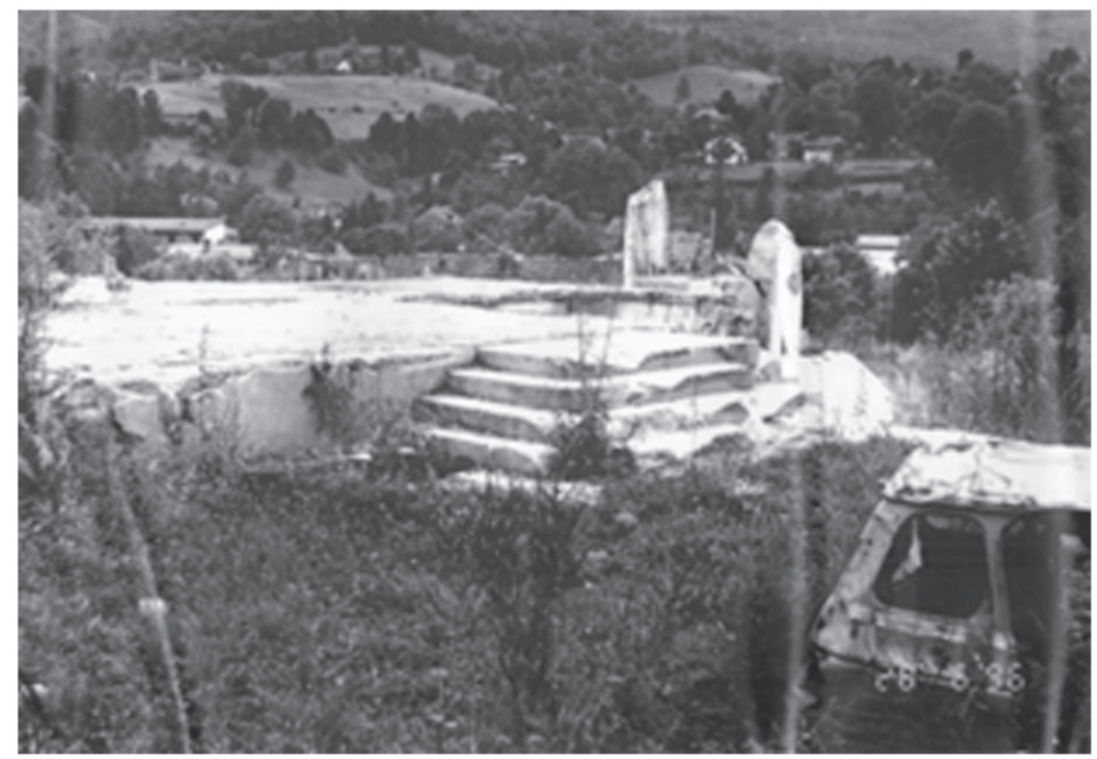

Ostaci porušene gradske džamije u Ključu

Rušenje gradske džamije u Ključu desilo se 30. jula 1992. godine u 03: 05. Rušenje je izvršeno miniranjem ${ }^{23}$ tako da je došlo do potpunog uništenje do temelja. Od siline eksplozije uništeni su ili oštećeni i objekti koji su se nalazili u blizini džamije. ${ }^{24}$ Teško je oštećena $i$ imamska kuća.

Džamija i mekteb u Biljanima izgrađeni su davne 1709. godine. Prema podacima iz popisa stanovništva i vjerskih objekata iz 1895. godine, u Biljanima je bila 1 džamija i 2 mekteba. Prva džamija u Biljanima sagrađena je u zaseoku Osmanovići, druga je podignuta u zaseoku Ćehići za vrijeme bivše Jugoslavije 1938. godine, a treća je sagrađena u Džaferagićima 1964. godine. Ova posljednja zapaljena je, a munara minirana 10. jula 1992. godine, kao i imamska kuća i mekteb. Mektebi u Jabukovcu i Botonjićima također su spaljeni do temelja i razrušeni iste godine. Pored rušenja navedenih objekata agresor je izvršio genocid nad muslimanskim življem džemata Biljani. Nova džamija u Biljanima

\footnotetext{
${ }^{23}$ AINOBiHPUB, Osnovni sud u Ključu, broj: Kri. 67/92, 30. juli 1992. ZAPISNIK O UVIĐAJU.

${ }^{24}$ Od posljedica eksplozije u znatnoj mjeri oštećene su kuće Kapetanović Mehe, Šabić Samida, uništene su stambene montažne barake i drugi objekti.
} 
izgrađena je na mjestu nekadašnje škole u kojoj su ubijani Bošnjaci. Pored ove džamije je šehidsko mezarje u koje su ukopani ubijeni Bošnjaci sela Biljani. Najstarija ubijena osoba iz Biljana imala je 90 godina, a najmlađe dijete (Amila Džaferagić) 3 mjeseca. ${ }^{25}$ Ostalo stanovništvo je protjerano, a selo opljačkano i spaljeno. Pored džamija bili su mektebi u naseljima Balagića-brdo, Jabukovac, Biljani i Osmanovići koji su isto uništeni. ${ }^{26}$

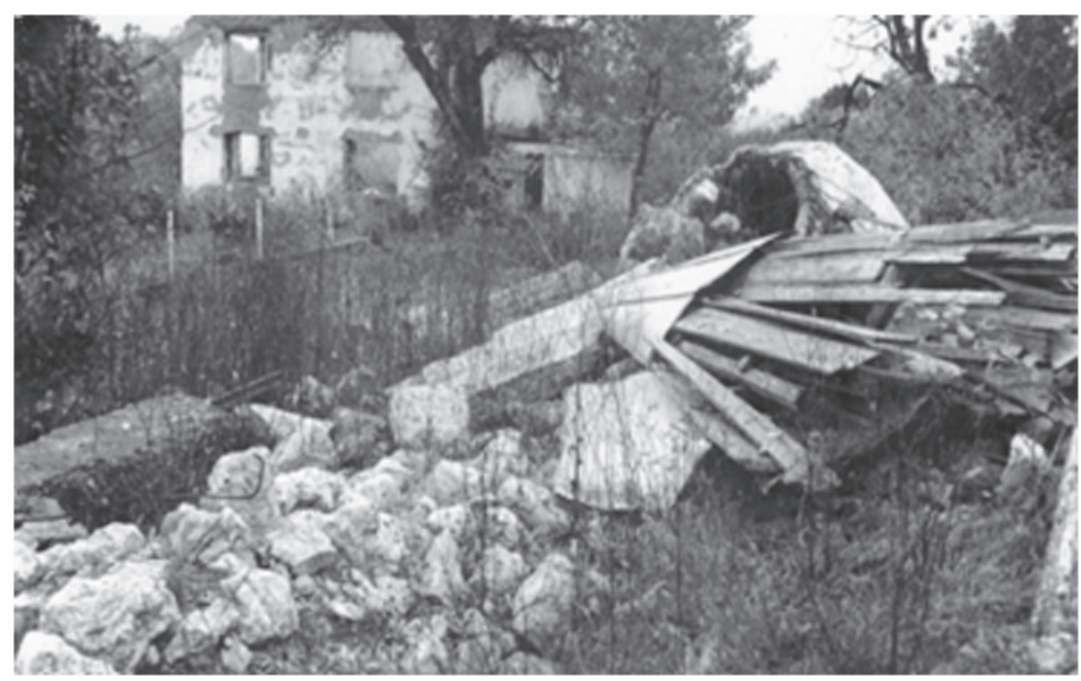

Ostaci porušene džamije u Biljanima

${ }^{25}$ M. Begić GENOCID U KLJUČU, str. 220.

${ }^{26}$ Arhiv Medžlisa IZ Ključ, INFORMACIJA O KULTUROCIDU SAKRALNIH OBJEKATA KULTURNO-HISTORIJSKOG NASLIJEĐA BOŠNJAKA OPĆINE KLJUČ, mart, 1998. godine. 


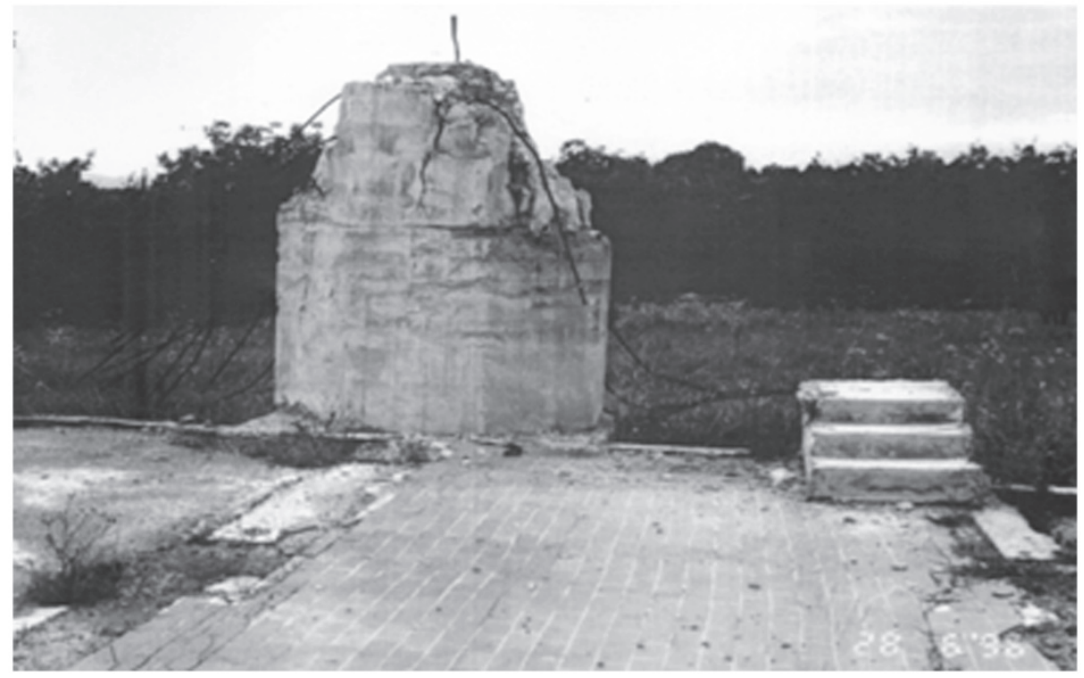

Porušena džamija u Krasuljama

Krasulje su naselje na putu Ključ - Sanski Most. Prema podacima iz popisa stanovništva i vjerskih objekata iz 1895. godine u Krasuljama su bile 2 džamije i 2 mekteba. Prva džamija u Donjim Krasuljama je izgrađena 1807. godine, a u džematu Gornje Krasulje 1833. godine. Nova džamija u Krasuljama izgrađena je 1985-1987. godine i bila je dimenzija 13×12 metara. Visina minareta bila je 32 metra. Tokom agresije na Republiku Bosnu i Hercegovinu porušena je 31. maja 1992. godine zajedno sa imamskom kućom.

Prvi mekteb u Ramićima izgrađen je 1760. godine, a džamija 1801. godine. Džamija je bila iznad sela i izgrađena od kamena s drvenim minaretom. Dimenzije džamije bile su 10x8 metara i nije bila u stalnoj upotrebi. Izgradnja nove džamije počela je 1987. godine, a dovršena je 1989. godine. Uz džamiju je izgrađena imamska kuća s mektebom. Tokom agresije na Republiku Bosnu i Hercegovinu 1992. godine zapaljena je i minirana džamija i imamska kuća. ${ }^{27}$

${ }^{27}$ Isto, str. 5. 


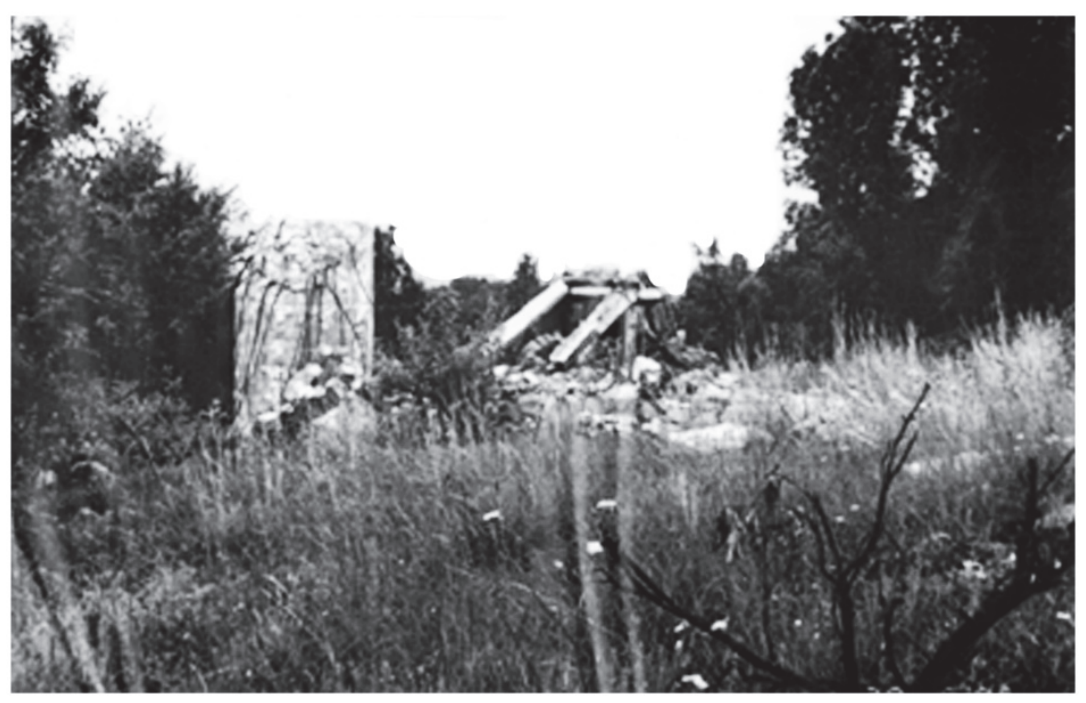

\section{Porušena džamija u Ramićima}

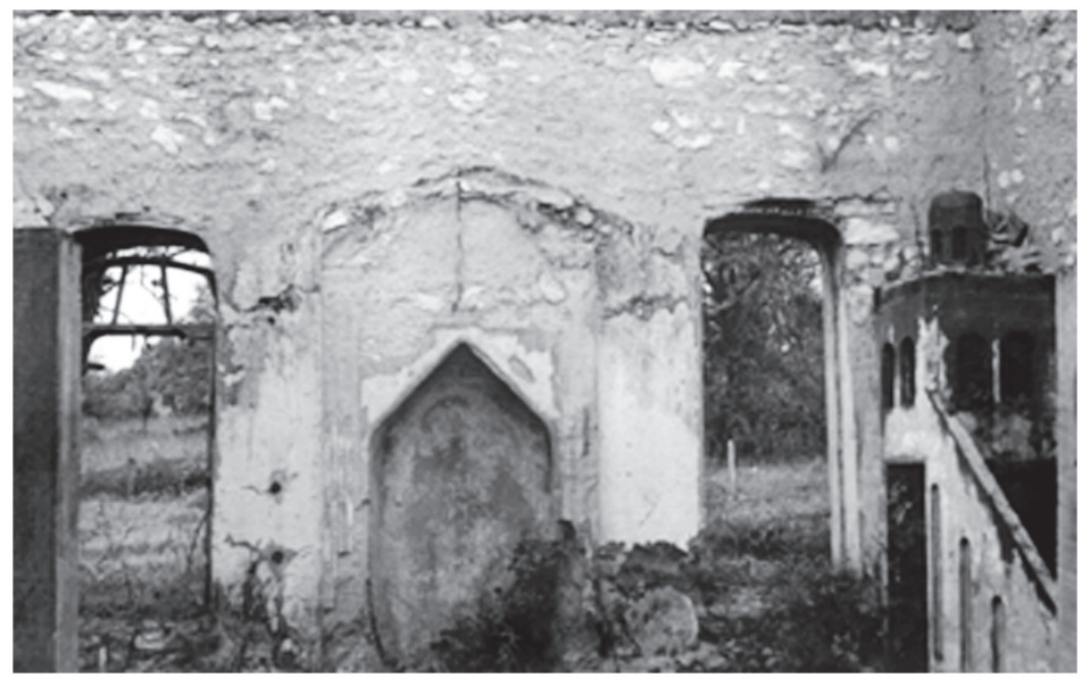

Unutrašnjost porušene džamije u Sanici

Prva džamija u Sanici izgrađena je krajem 16. stoljeća. Bila je izgrađena od drveta $\mathrm{s}$ drvenim minaretom visine 15 metara. Druga džamija izgrađena je krajem osmanske vladavine na ovim prostorima. Ova džamija bila je kamena s drvenim minaretom iste visine. Zbog dotrajalosti, džamija je porušena i na istom mjestu 1937. godine sagrađena nova. 
Nova džamija je izgrađena od kamena s drvenim minaretom. Drveni minaret je skinut 1978. godine i izgrađen armirano-betonski minaret. Sanička džamija zapaljena je 26. juna 1992. godine, a 1. augusta 1992. godine miniranjem je srušen minaret. Uništena je i imamska kuća. ${ }^{28}$ Džamija u džematu Šljivari izgrađena je za vrijeme osmanske uprave. $\mathrm{Na}$ istom mjestu 1963. godine renovirana je postojeća džamija koja je porušena 1992. godine. ${ }^{29}$ Prema podacima iz popisa stanovništva i vjerskih objekata iz 1895. godine, Sanica je imala jednu džamiju i jedan mekteb.

Prva džamija u zaseoku Tičevići izgrađena je krajem 17. stoljeća. Na mjestu prve džamije 1937. godine izgrađena je kamena džamija s drvenim minaretom koja je bila okovana limom. Pored džamije u naselju Tičevići bila kuća za imama s mektebom. U agresiji na Republiku Bosnu i Hercegovinu, 29. maja 1992. godine spaljena je džamija i imamska kuća od strane pripadnika srpskih vojnih i policijskih snaga SJB Ključ. ${ }^{30}$

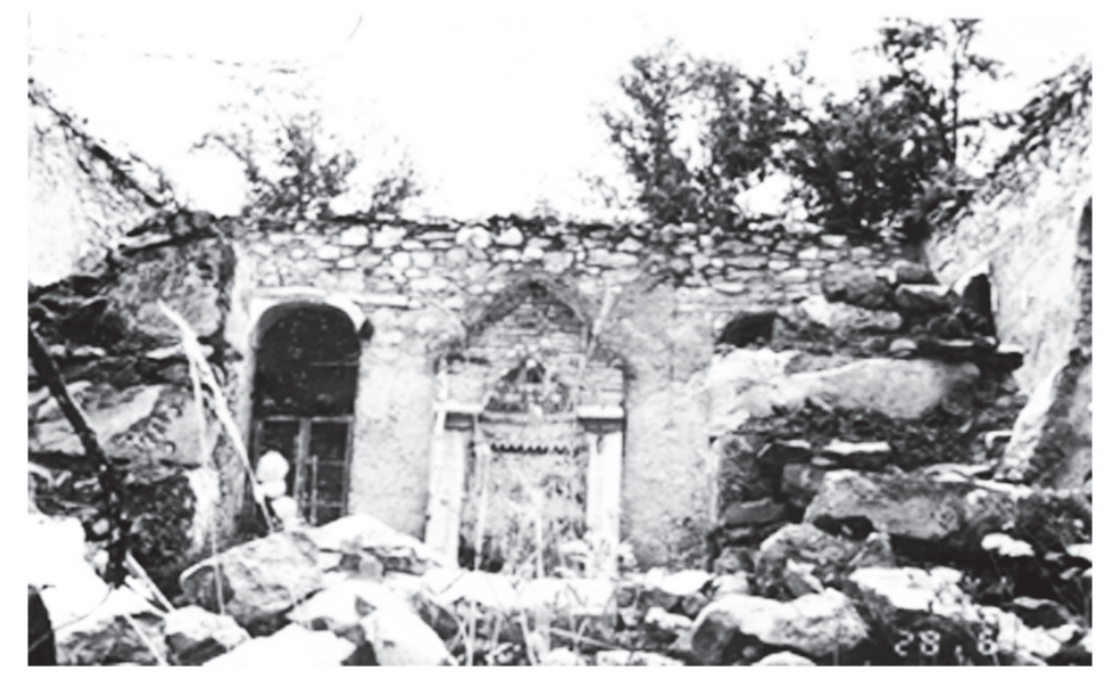

Unutrašnjost porušene džamije u Tičevićima

\footnotetext{
${ }^{28}$ Isto, str. 15-16.

${ }^{29}$ Isto, str. 15.

${ }^{30}$ Isto, str. 4.
} 
Mekteb u naselju Vojići prvi put je spaljen je u toku Prvog svjetskog rata, drugi put u toku Drugog svjetskog rata i konačno 1992. godine. Tako da je u svim ratovima na ovom prostoru bio spaljivan. ${ }^{31}$

Džamija u naselju Kamičak najvjerovatnije je bila u srednjevjekovnoj utvrdi, gdje je vojna posada u jednom dijelu prilagodila prostor za džamiju kako bi mogli obavljati molitvu. Prema pisanim podacima prva džamija u Kamičku izgrađena je 1679. godine. Na osnovu popisa stanovništva i vjerskih objekata iz 1895. godine, Kamičak je imao jednu džamiju i dva mekteba. U Prvom svjetskom ratu prva džamija je uništena, da bi nakon toga bila obnovljena. Sve džamije su građene i obnavljane na istoj lokaciji. Džamije su bile kamene s drvenim minaretima. Neposredno pred agresiju džamija je proširena i obnovljena. Izgrađen je armirano-betonski minaret. Tokom agresije na Republiku Bosnu i Hercegovinu pripadnici srpskih vojnih i policijskih snaga porušili su minaret, opljačkali i devastirali džamiju, a imamsku kuću srušili. ${ }^{32}$

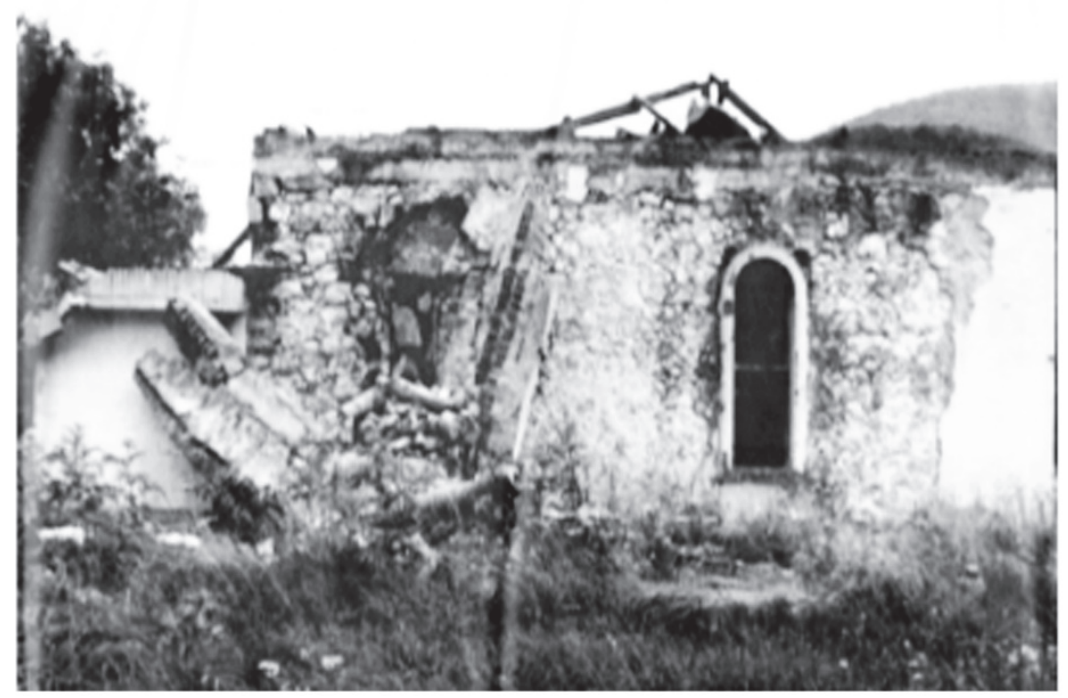

Porušena džamija u Kamičku

\footnotetext{
${ }^{31}$ Isto, str. 5.

${ }^{32}$ Isto, str. 11.
} 
Novu džamiju u Velagićima mještani su počeli graditi 1989. godine, i nije bila zvanično otvorena. Dimenzije džamije bile su $15 \times 13$ metara s minaretom visine 35 metara. Džamija je bila s kubetima. Minirana je od strane srpskih snaga polovinom juna 1992. godine. Od siline eksplozije u potpunosti je porušena. Ostaci materijala od džamije nalazili su se na udaljenosti od nekoliko stotina metara. S ove džamije skinut je bakarni lim i ugrađen na krov pravoslavne crkve u selu Šljivno na Manjači. Taj bakarni lim morali su skidati Bošnjaci - logoraši iz logora Manjače i ugraditi ga na krov pomenute crkve.

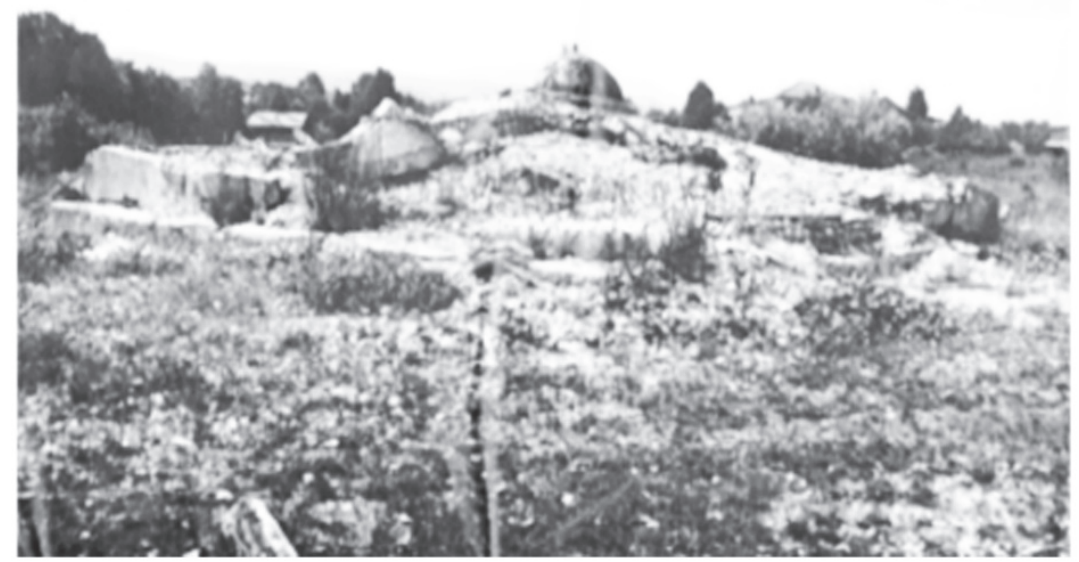

Porušena džamija u Velagićima

Džamija u naselju Husići izgrađena je 1809. godine. Izgrađena je od kamena s drvenim minaretom koji je bio okovan limom. Dimenzije džamije bile su 10x9 metara, a visina minareta 22 metra. Džamija je zapaljena 1941. godine od strane četnika. U neposrednoj blizini džamije bila su i dva turbeta koja su porušena i zapaljena kada i džamija. Nakon Drugog svjetskog rata, 1946. godine džamija je obnovljena. Juna 1992. godine ponovo je zapaljena od strane pripadnika srpske vojske i policije. 


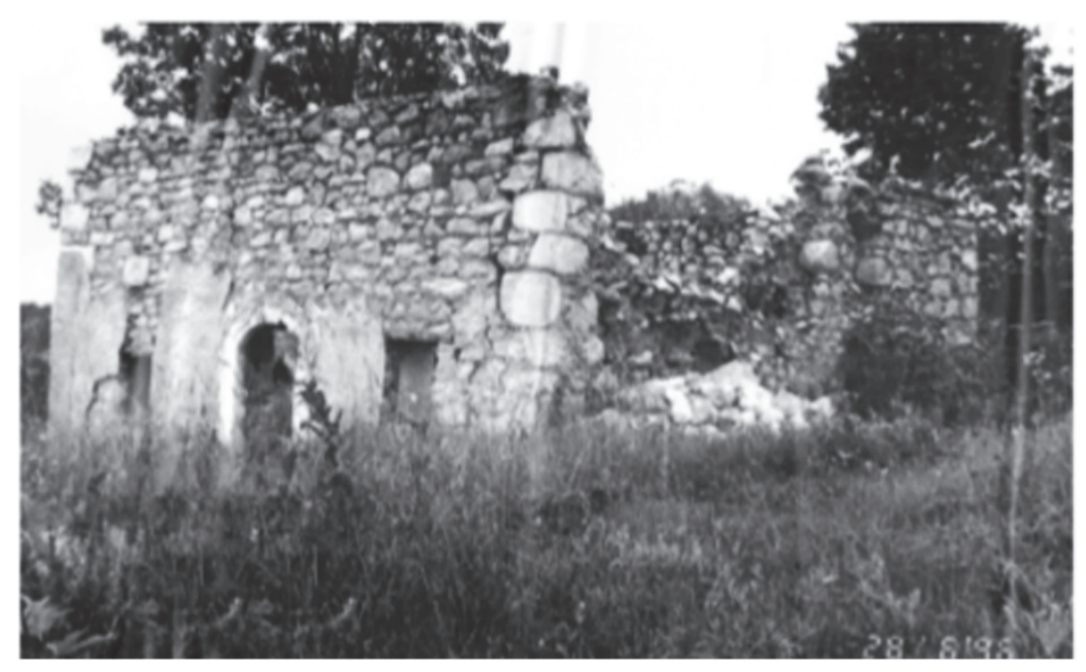

Porušena džamija u Husićima

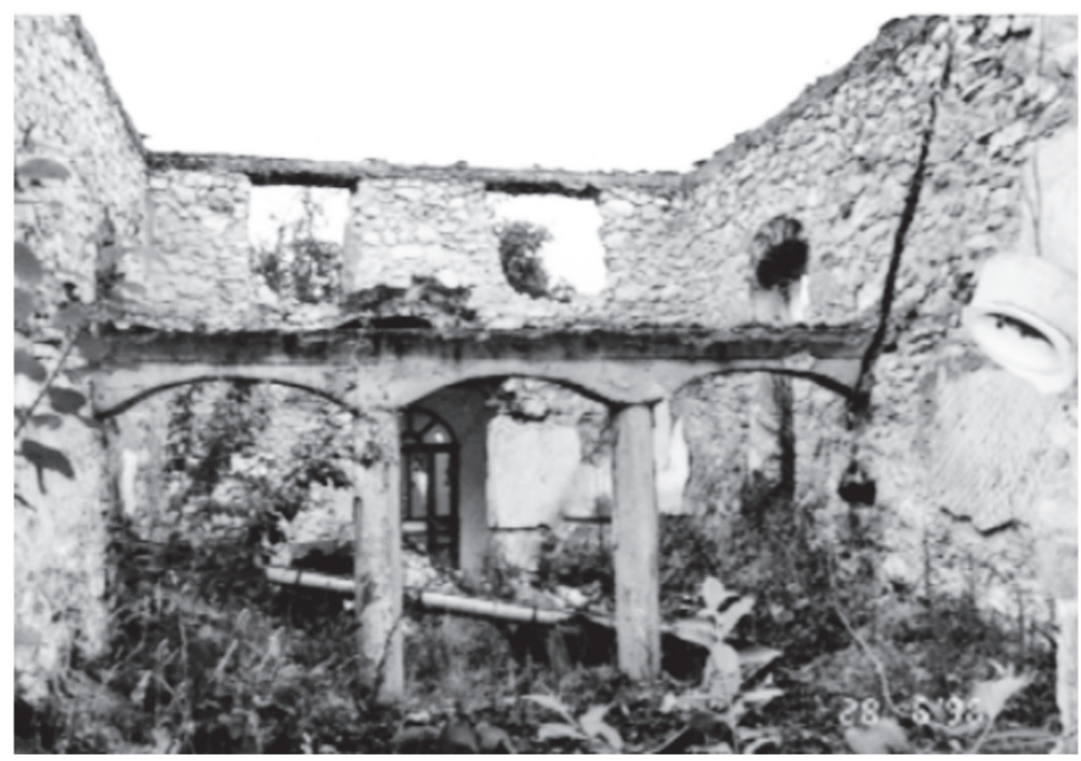

Porušena džamija u Humićima

Prvi mekteb u Humićima izgrađen je 1760. godine, a prva džamija 1771. godine. Džamija u ovom džematu spada u najstarije ključke džamije. Tokom Drugog svjetskog rata džamija je ostala neoštećena. Ova džamija je obnovljena i proširena. Njene dimenzije su bile 12x9 metara. Kao i većina ključkih džamija izgrađena je od kamena s 
drvenim minaretom. Uz džamiju je bio i harem. Tokom agresije, 4. augusta 1992. godine porušena je džamija i imamska kuća. Ovdje treba napomenuti da su u naseljima Vukovo selo, Plemenice i Ljutića brdo postojali mektebi koji su uništeni u agresiji. ${ }^{33}$

U naselju Balijevići u vrijeme osmanske uprave bio je izgrađen mekteb u kojem se izvodila vjerska poduka. Poslije Drugog svjetskog rata ponovo je izgrađen mekteb. Prva kamena džamija dimenzija 9x8 metara s drvenim minaretom izgrađena je 1982. godine. U augustu 1992. godine džamija je spaljena i uništena.

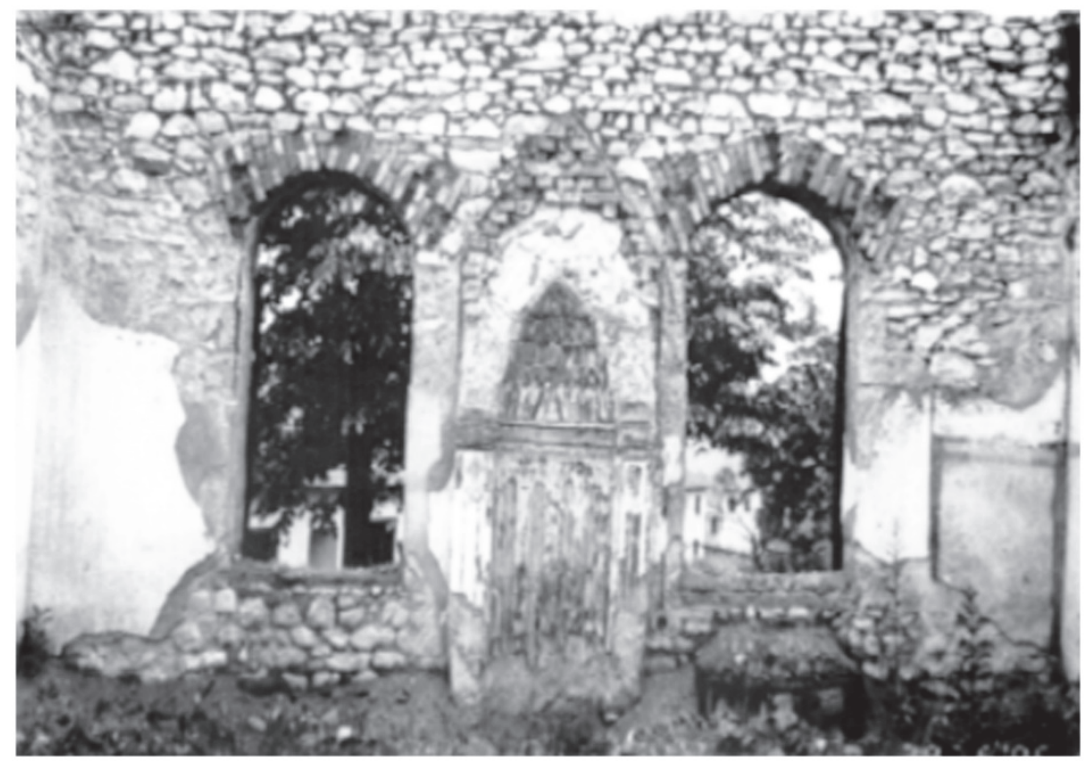

Porušena džamija u Balijevićima

33 Isto. 


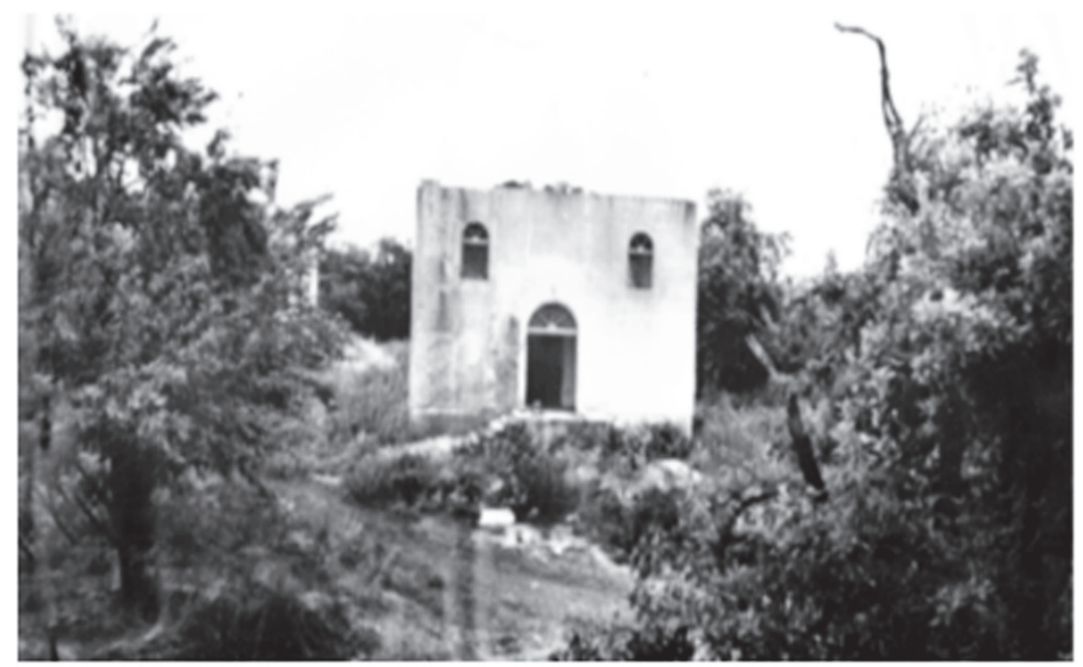

Porušena džamija u Crljenima

Prvi mekteb u Crljenima izgrađen je 1770. godine, a prva džamija 1791. godine. Naselje Crljeni i džamija su spaljeni 1941. godine od strane četničkih jedinica. Nakon Drugog svjetskog rata izgrađena je drvena džamija s drvenim minaretom visine 28 metara. Nakon zemljotresa 1969. godine džamija je pretrpjela znatna oštećenja i morala je biti porušena. Nova džamija je sagrađena 1972. godine i nije imala minaret. U agresiji na Republiku Bosnu i Hercegovinu ova džamija je u potpunosti opljačkana i devastirana tako da su ostali samo zidovi. ${ }^{34}$

Prvi mekteb u naselju Budelj izgrađen je 1795. godine dok je prva džamija sagrađena 1805. godine. Napravljena je od kamena s drvenim minaretom. Džamija je potpuno rekonstruisana i renovirana 1980. godine. U sastavu džamije nalazio se dio za molitvu, za mekteb, abdesthana, gasulhana i sanitarni dio. Dimenzije džamije bile su 12x11 metara. Tokom agresije na Republiku Bosnu i Hercegovinu, 27. juna. 1992. godine džamija je porušena od strane srpskih vojnih i policijskih snaga. $^{35}$

${ }^{34}$ Arhiv Medžlisa IZ Ključ, INFORMACIJA O KULTUROCIDU SAKRALNIH OBJEKATA KULTURNO-HISTORIJSKOG NASLIJEDA BOŠNJAKA OPĆINE KLJUČ, mart, 1998. godine.

${ }^{35}$ Isto, str. 15. 


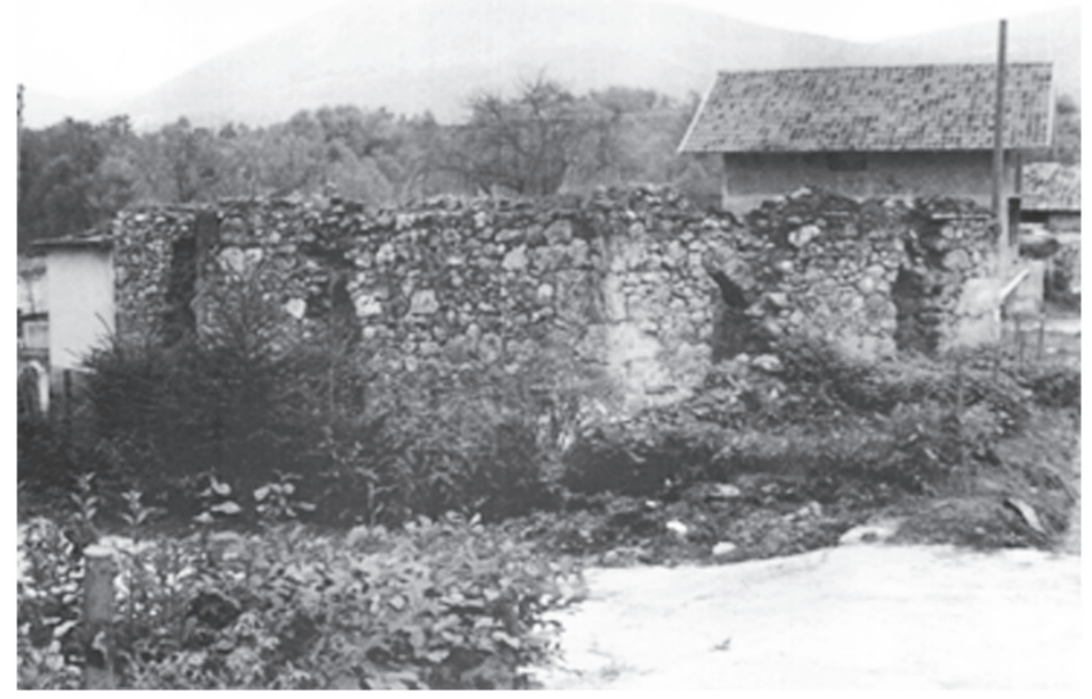

Porušena džamija u Gornjem Budelju

Džamija u Zgonu izgrađena je 1759. godine. Izgrađena je od drveta s drvenim minaretom. Ova stara džamija je porušena 1933. godine. Nova džamija od kamena s drvenim minaretom, visine 20 metara, izgrađena je 1935. godine. Ovu džamiju su zločinci spalili 1942. godine. Na istom mjestu i s istim dimenzijama 1946. godine izgrađena je nova džamija. Dimenzije ove džamije bile su 10x9 metara. Usljed dotrajalosti, 1989. godine ova džamija je porušena i na istom mjestu sagrađena je nova. Novosagrađena džamija nije imala minaret, ali je bio pripremljen materijal za izgradnju. U agresiji na Republiku Bosnu i Hercegovinu džamija je temeljito opljačkana, odnesen je materijal koji je bio pripremljen za izgradnju minareta. ${ }^{36}$

${ }^{36}$ Isto, str. 14. 


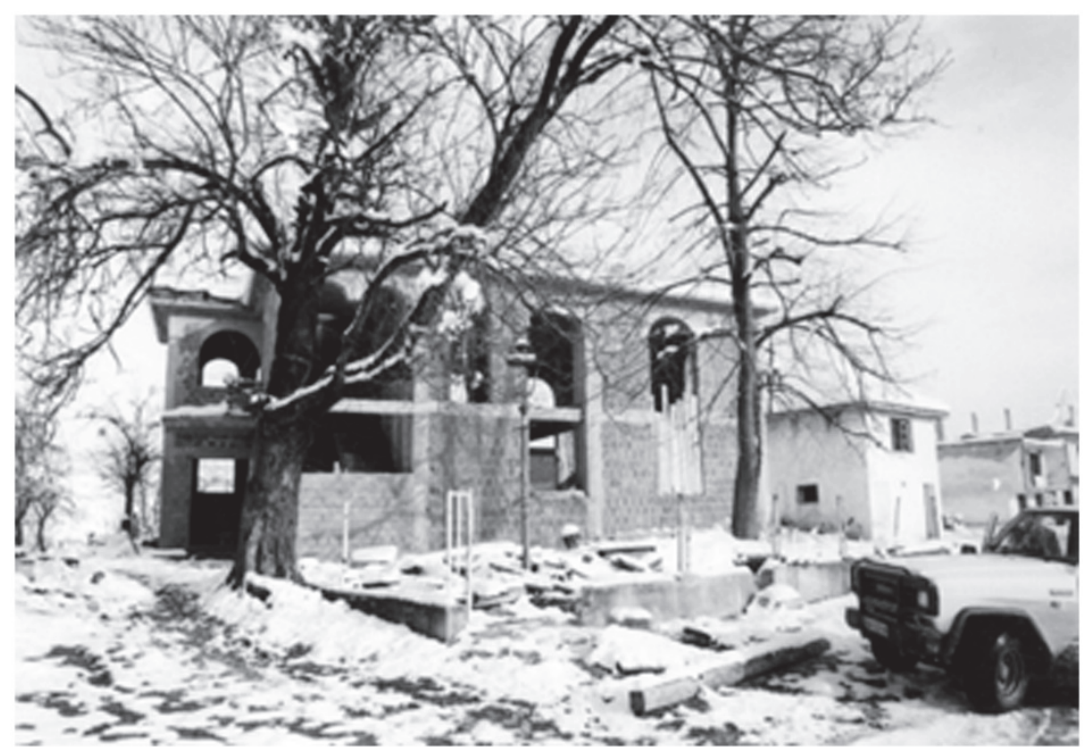

Neizgrađena džamija u Zgonu (slika 1996. godine)

Džamija u Dubočanima izgrađena je za vrijeme osmanske uprave i bila je prva izgrađena u ovom mjestu. Prva kamena džamija izgrađena je u periodu austrougarske vlasti u Bosni i Hercegovini. Zapaljena je 1942. godine. Nakom rata ova džamija je obnovljena s drvenim minaretom koji je bio okovan limom. U nekoliko navrata je renovirana kada je i prekrivena crijepom. U toku agresije na Republiku Bosnu i Hercegovinu 1992. godine porušena je od strane agresora. Zapaljena je i imamska kuća. ${ }^{37}$

${ }^{37}$ Isto, str. 13. 


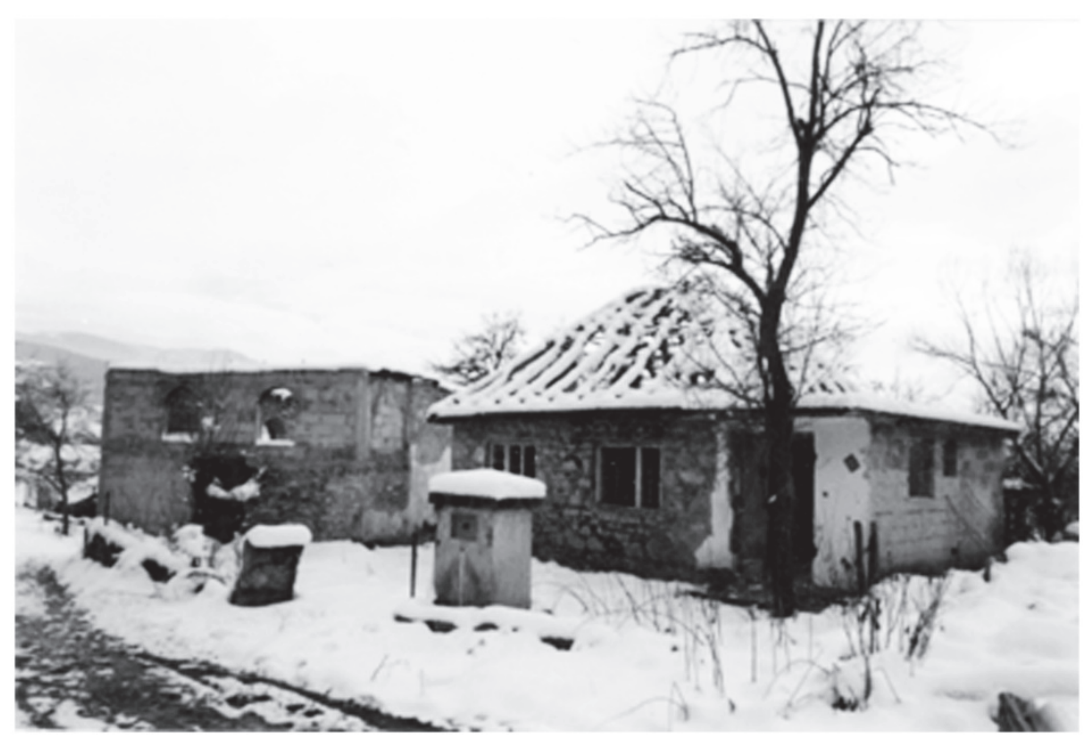

Ostaci uništene džamije u Dubočanima

Velečevo je prvu drvenu džamiju imalo za vrijeme osmanske uprave. Ova džamija je porušena tokom Prvog svjetskog rata. Na istom mjestu sagrađena je kamena džamija dimenzija 10x10 metara. Džamija s imamskom kućom je spaljena u toku Drugog svjetskog rata. Nakon Drugog svjetskog rata, 1947. godine izgrađena je kamena džamija dimenzija 12x10 metara bez minareta. Uništena je 1992. godine od strane pripadnika srpskih vojnih i policijskih jedinica. ${ }^{38}$

${ }^{38}$ Isto, str. 13. 


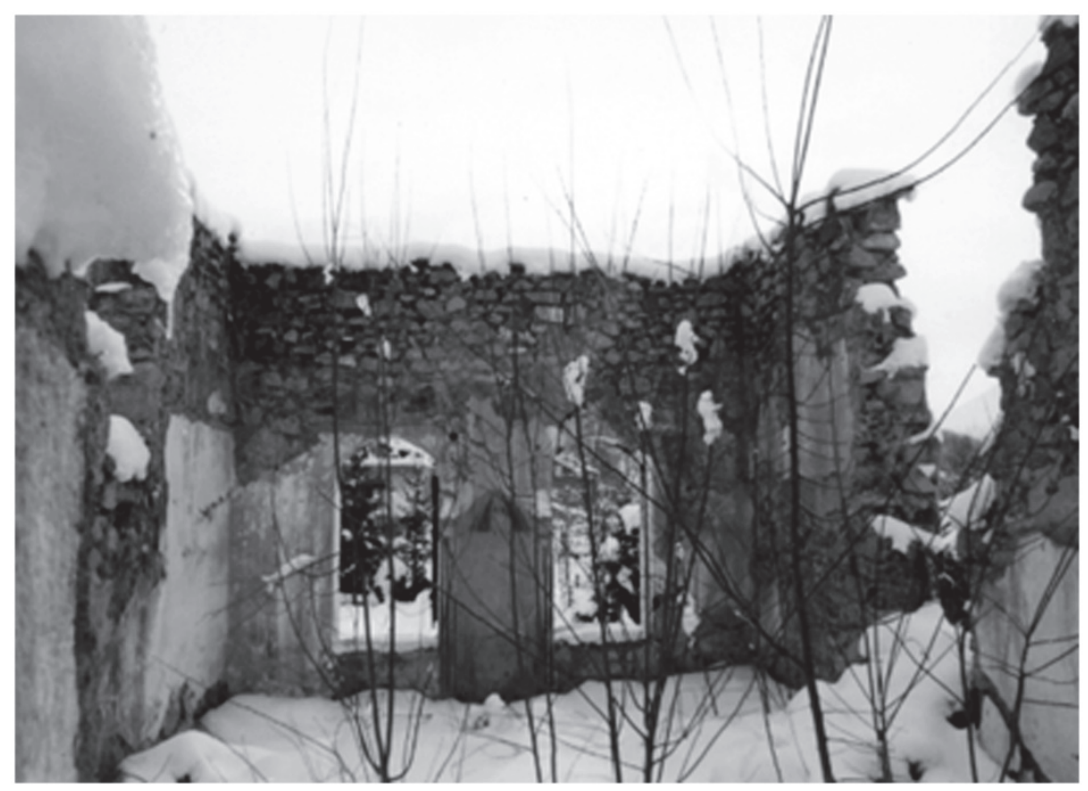

Unutrašnjost uništene džamije u Velečevu

\section{Zaključak}

Uništavanje vjerskih objekata (džamija, tekija, mesdžida, imamskih kuća i stanova, objekata Islamske zajednice, turbeta, mezarja) nisu bila djela pojedinaca nego su bila unaprijed planirana, smišljena, sistematična i široko rasprostranjana djela usmjerena prema Bošnjacima - muslimanima. Uništavajući zaštićene objekte, nije uništavana bošnjačka kultura kao pojedinačna, nego je uništavana svjetska baština, jer su one dio svjetske kulture. Na prostoru Bosanske krajine nastojali su se ukloniti svi materijalni dokazi o postojanju drugih naroda, izuzev srpskog. Sistematično su paljeni, minirani, rušeni i uklanjani vjerski i kulturno-historijski spomenici Bošnjaka i Hrvata. Na vjerskim objektima (džamijama, mesdžidima, mektebima, imamskim kućama) na području općine Ključ uništeno, devastirano ili opljačkano je 29 objekata sa procijenjenom štetom od 8.965.000 KM. 


\section{Literatura}

\section{a) Izvori}

1. Arhiv Instituta za istraživanje zločina protiv čovječnosti i međunarodnog prava Univerziteta u Sarajevu.

2. Arhiv Medžlisa Islamaske zajednice Ključ.

3. Arhiv Instituta za nestale osobe Bosne i Hercegovine - Područni ured Bihać.

\section{b) Knjige}

4. Mujo Begić, (2016) Bosanska Krupa 1992-1995. - Porušeni grad, Institut za istraživanje zločina protiv čovječnosti i međunarodnog prava Univerziteta u Sarajevu, Sarajevo.

5. Mujo Begić, (2015) Genocid u Prijedoru, Hrvatski memorijalnodokumentacijski centar Domovinskog rata Zagreb, Institut za istraživanje zločina protiv čovječnosti i međunarodnog prava Univerziteta u Sarajevu, Zagreb, Sarajevo.

6. Mujo Begić, Senadin Ramić, Zlatan Ališić, (2015) Tomašica masovna grobnica, Institut za istraživanje zločina protiv čovječnosti i međunarodnog prava Univerziteta u Sarajevu, Sarajevo.

7. Mujo Begić, (2012) Genocid u Ključu, Institut za istraživanje zločina protiv čovječnosti i međunarodnog prava, Sarajevo.

8. Muharem Omerdić, (1999) Prilozi izučavanju genocida nad Bošnjacima (1992-1995), El-Kalem, Sarajevo.

9. Muharem Omerdić, (2005) Imami šehidi, Udruženje Ilmije, Sarajevo.

10. Norman Cigar, (2000) Uloga srpskih orijentalista u opravdanju genocida nad Muslimanima Balkana, Institut za istraživanje zločina protiv čovječnosti i međunarodnog prava u Sarajevu, Sarajevo.

11. Smail Čekić, (2016) Dejtonski (mirovni) sporazum - Legalizacija genocida u Republici Bosni i Hercegovini, Institut za istraživanje zločina protiv čovječnosti i međunarodnog prava Univerziteta $u$ Sarajevu, Sarajevo.

12. Zbirka propisa, (1979) Međunarodne konvencije o ratnom pravu i sigurnosti, ZONO, Zagreb. 


\title{
DESTRUCTION OF MOSQUES AND OTHER FACILITIES OF THE ISLAMIC COMMUNITY OF BOSNIA AND HERZEGOVINA IN THE MUNICIPALITY OF KLJUC̆
}

\author{
MA Ermin Vučkić \\ E-mail:erminvuckic@yahoo.com \\ PhD Mujo Begić, Islamic Faculty of Pedagogy \\ University of Bihać \\ E-mail:mujo_begic@hotmail.com
}

Summary

During the aggression against the Republic of Bosnia and Herzegovina, religious objects and other property of the Islamic Community in Bosnia and Herzegovina has been attacked by Serbian military and police forces without restriction. Destruction, devastation, looting and wanton destruction were intended to erase the traces of the existence of Islam and Bosniaks in this region. Destroying mosques, masjids, imam's houses, cemeteries and other waqf properties has caused enormous material damage to the Islamic community. Numerous religious sites that were protected cultural and historical monuments were destroyed. According to an identical scenario, mosques and other properties of the Islamic Community in the municipality of Kljuc were destroyed or significantly damaged by members of the Serbian military and police forces.

Keywords: aggression, mosques, destruction and devastation of Islamic Community propertyin Bosnia and Herzegovina. 


$$
\text { رئيس الأمَّة لمجتير أرمين ووتسكيتش المشخة في كليوتش }
$$

E-mail:erminvuckic@yahoo.com

الدكتور المحاضر مويو بغيتش

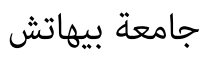

كلية التربية الإسلامية، كلية التربية

معهد المفقودين في البوسنة والهرسك - المكتب الإقليمي في بيهاتش الربة

E-mail:mujo_begic@hotmail.com

\section{تدمير المساجد وغيرها من مرافق المشخة الإسلامية في البوسنة والهرسك في بلدية}

$$
\text { كليوتش }
$$

\section{الملخص}

خلال العدوان على جمهورية البوسنة والهرسك، تعرضت المرافق المشخة الإسلامية

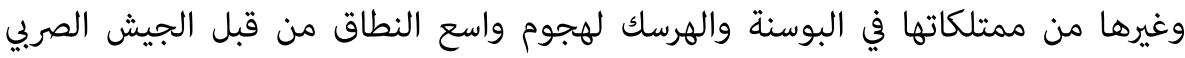

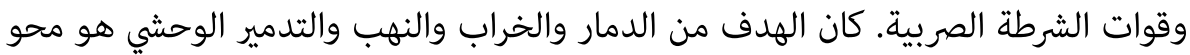

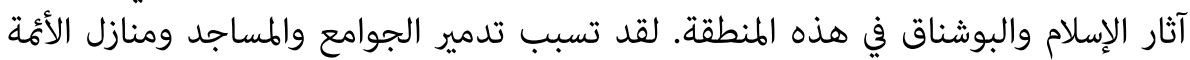

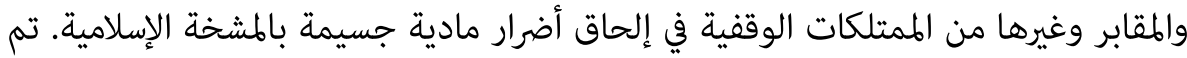

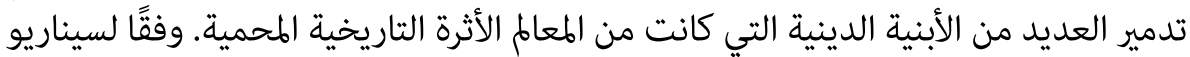

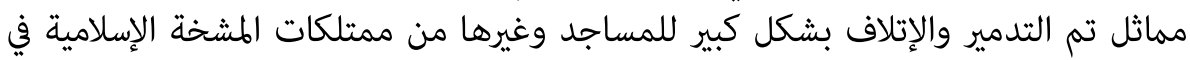

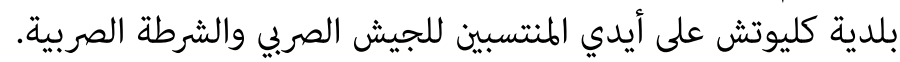

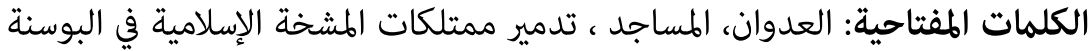
والهرسك وإلحاق الأضرار بها. 